\title{
The Firebird: A Literary Projection of Socio-Political Cogitations of Hasan Azizul Huq
}

Irina Ishrat

Assistant Professor, Department of English, Daffodil International University, Bangladesh

*Corresponding author: Irina Ishrat

Abstract

This study would like to examine Hasan Azizul Huq's The Firebird with a view to unveiling the practical picture of socio-political crisis and communal riots of the $20^{\text {th }}$-century Indian Subcontinent. It aims to foster the real image of displacements, civil war, genocide, poverty, famine, and so on. Throughout his literary career, Huq has protested the dishonest politicians and bureaucrats with a view to exposing the true color of their characters. For signifying the practical image of corrupt politics and unsocial activities of the age, the novelist has taken his pen to write down in the form of fiction and story. As a minute observer of society and politics, he has practically shed new light on different issues of human character. His superb making creation of an anonymous female protagonist feels the necessity of freedom and existence of her birth land, for which she goes beyond the decision of the patriarchal rule and order. His novel focuses on freedom of movement, exclusion of British products, famine of '43, partition of ' 47 , and the two riots of the Muslim and the Hindu communities. Also, this study would like to apply the conflict theory of socio-political concerns made by Karl Marks, Tim Dunne, Milja Kurki, Smith Steve, and Kenneth Waltz. For this purpose, it aims to explore Hasan Azizul Huq's treatment of socio-political concerns with reference to his epoch-making creation The Firebird.

Keywords: Hasan Azizul Huq, The Firebird, Socio-Political Cogitations, and Communal Riots.

Copyright @ 2020: This is an open-access article distributed under the terms of the Creative Commons Attribution license which permits unrestricted use, distribution, and reproduction in any medium for non-commercial use (NonCommercial, or CC-BY-NC) provided the original author and source are credited.

\section{INTRODUCTION}

Hasan Azizul Huq is one of the most popular and familiar short story writers in the history of Bengali literature. Besides being devoted to writing short stories, Haque has investigated treaties. His contribution to enriching socio-political and cultural literature is unforgettable. Bengali literature owes to Hasan Azizul Huq for its enrichment and development. If Huq did not write socio-political concerns in the form of novel, story and treatise, many aspects of Bengali literature would be unknown to us. Litterateur Hasan Azizul Huq has unveiled his contemporary socio-political and cultural elements in his well-popular novel The Firebird, which may be deemed as a pure document of partition and communal riots between the Hindu and the Muslim communities. In this regard, Kousik Ahmed opines: "Huq very subtly and stylistically in The Firebird focuses on politics, social criticism, religion, country, partition, boundary, and diaspora in such a way that it seems to be impossible for him to retreat. Then the fact can be acknowledged that Hasan Azizul Huq has spent forty-years before composing novels; he has spent those years entirely for preparing novels indeed" [1].

During the World War II, Huq was born while the nations of the world were suffering from the national and international political crisis. Famine, food and cloth crisis, partition, riots, and displacement have deeply touched his literary loving mind and heart. Especially, partition and contemporary Hindu-Muslim riots have occupied a remarkable place in his realm. Later, witnessing such type of partition cruelly and mercilessly, he is compelled to accept the turbulent reality of partition and rots without any protest. That tragic pain and mental agony have become glaring concerns in his writing. Partition is not only a political or geographical concern, but also rape, killing, abduction, envy, loot, displacement, oppression, condemnation, eviction, refugee crisis, fear, and panicall of which are dealt with his literary cannon. Huq's portrayal of characters does not know about the political crisis of partition. Before leaving the country, even they do not think that they would be the inhabitants of a new country through sacrificing land, property, and 
livelihood. Due to the communal politics of the selfish and greedy politicians, partition has created a new colonial milieu in the mind of Bengalese. Huq's portrayal of male and female characters is humble and obedient to each other. Each character has to face the complex reality of life at every step, where Huq subtly wants to prove that partition is meaningless in the light of religion. Instead it is indeed a historical wrong and foolish act.

However, Huq has created each character very skillfully in such a way that the novelist wants to share his bitter experiences through the art of characterization, plot-construction, setting, and space. One may think that he has no imaginary character in his story and fiction. But it is true that each character plays his role as a representative of a particular age. Each character has a unique feature for which they are different from each other. In Huq's art of characterization, it is noticed that a minor character is devoted to creating his or her self-identity and autonomy. In this way, Huq tries to create innovative and dynamic male and female characters. His stories and fiction show his artistic excellence and skill. He has realized the fact that political leaders do politics just for their personal interest and motif [2].

Indeed, Huq's epoch-making creation The Firebird has achieved popularity among academicians, students, mentors, and research scholars in the Indian Subcontinent. Nowadays, it can be mentioned here that in the Bengali Department of the undergraduate and graduate levels, this novel is being taught, investigated, and studied by students and teachers. It needs no telling the fact that many researchers are doing their research projects on this time-winning novel The Firebird through shedding new light on partition, communal riots, socio-political and cultural concerns.

In this regard, the current researcher can apply the conflict theory of Karl Marx to investigate Huq's treatment of socio-political cogitations and cognitions in the light of his novel The Firebird. However, of the classical founders of social science, conflict theory is associated with Karl Marx (1818-1883). According to Marx (1848):

The history of all hitherto existing society is the history of class struggles. Freeman and slave, patrician and plebeian, lord and serf, guild-master and journeyman, in a word, oppressor and oppressed, stood in constant opposition to one another, carried on an uninterrupted, now hidden, now open fight, a fight that each time ended, either in a revolutionary re-constitution of society at large, or in the common ruin of the contending classes [3].

Here, Marx has expressed his view regarding social criticism and class struggle, where freeman and slave, patrician and plebeian, master and slave, oppressed and oppressor stand in opposition to each other and where they are bound to fight against each other to acquire their basic needs and rights. Similarly, Huq's The Firebird signifies the socio-political conflicts and struggle of the $20^{\text {th }}$-century Indian Subcontinent's nations to hold their rights and freedom so that they can live safely and freely together in free and fair society and community.

\section{Socio-Political Cogitations of Hasan Azizul Huq}

Hasan Azizul Huq was born in the year 1939. After his birth, the socio-political chaos of the liberation movement of the Indian Subcontinent has greatly impacted on his pure mind. Not merely that, global political crisis, economic crisis, World War II, psychological alienation and disintegration, colonial rule and domination have also touched his heart, whose reflections one can see in the novel The Firebird. In his language, Huq writes:

I was born in thirty-nine, a dreadful famine broke out in forty-three, and then war was going on randomly, the war ended in forty-five. The communal riots were getting happened in fortysix, and partition took place in forty-seven. Have you understood? All events took place in my lifetime. What I have seen everything will not be mentioned here. I smell dribs and drabs of that weather. I smell of bloody war, starvation, and famine in my village. I have realized that many families are passing their unhappier days along with starvation. We were a well-to-do family. We began to prosper day by day for several generations. The familial condition was somewhat better in my generation. On the contrary, everything got devastated abruptly before my eyes. Everyone knows the ups and downs of the forties [4]. [My translation]

Starting from the All India Quit Movement to partition, communal riots, refugee crisis, and displacement, famine, and cloth and food crisis-all sorts of deadliest events have greatly been reflected in his novels. Partition is one of the cardinal questions in his literary realm. Huq is a creative and versatile novelist indeed in our judgment. In his core philosophy, this sort of crisis seems to be very severe and turbulent. He loves his birthland Bardhhaman, which is exposed to his artistic excellence. His artistic creation is of its evidence. If one looks at his artistic realm, his birthland Bardhhaman shows his cogitations and cognitions of sovereignty and the nations very apparently. None of his memory is confined to the map of Rarh. Even the primitive language of Rarh, people, culture, nature, and struggle-all of which have become the subject matters of his stories and fictions, and which have turned into artistically Bengalese movement, regeneration, and liberation movement. In this regard, the novelist opines in the following: 
I left West Bengal in 1954 and began to write stories since the year 1960. There was a gap of six-years. I spent sixteen years of my life there since the year 1954. While a man begins to grow up, he slowly realizes the width of youth. Because the width of the entire life varies from the width of youth, where youthful reminiscence weighs heavy if it is kept in the balance. So, after I depart from that land, while I have tried to discover the core philosophy of my life, birthland, nature, landscapes, and fellow beings are existed and have brightened in my heart and mind purely, what I have left is similar to that land indeed. [5] [My translation]

Huq has exposed his sixteen-year' reminiscence of Bardhhaman in his stories, treatise, and above all, fiction. He has written that his first novel, The Firebird, bears the socio-political crises of partition, famine, and communal riots, where there stands his familial tragedy. His fictional diction emerges from Rarh's. As a head figure of the village, Huq's father protested and fought against partition and communal riots. He witnessed standing very nearly Hindu-Muslim riots, genocide, and bloody war. Since his childhood, Huq was a very talented and logical man. He tries to judge everything very consciously. In the Calcutta riot, a poor and helpless girl Lakkhi of a certain village, was killed cruelly and mercilessly by the Muslim rioters. Boy Azizul Huq got shocked mentally, witnessing such a merciless incidence. Being severely upset, his mind echoes thus:

Nothing happened to anybody; in-between, the sun abruptly disappeared from me. The light spreads around, but I do not see its glimpse anywhere. It seems to me that while the rain will come down from heaven, everybody will fall onto the ground. I feel empty, I feel the darkness in mind; how mercilessly and cruelly a poor and helpless girl Lakkhi was killed inside the room, in the veranda, on the way? In the morning, at noon, and in the evening! How many rioters killed her, and how they killed her? Before chopping, perhaps she raised her hands not to kill. Please do not kill me. My father begs from door to door. Why I feel this, I do not know [6]. [My translation]

Huq has refuted communal riots and partition. $\mathrm{He}$ has raised lots of questions regarding partition. He has protested those selfish politicians and rioters who have wanted to divide the country for their self-interest. Indian party politics is the driving force of his familial and personal concern. According to Dunne et al. "Politics is all about power struggle and the struggle is not separable from social life itself" [7]. For this situation, his ponderance over the partition and political crisis is very apparent and faithful. Though the role of the Muslim in the Indian Freedom of Movement seems to be little, Muslim leader Jinnah demands a different country for the Muslim Community that Huq does not support. Partition and freedom of the country are meaningless to the novelist. Unity of life and livelihood, thousands of years of Hindu-Muslim culture and tradition have been broken down owning to partition and communal riots. Huq regards partition as the power monger. In his opinion: "Freedom of Indian Subcontinent has not emerged with the words of victory, but from screams of hundreds and thousands of the common men, women, and children" [6]. [My translation] From partition, the fact is apparent that the different state was not established, and it was not feasible too. But the common people fall victim to political betrayal and the conspiracy of the political leaders. Communal riots do not stop; rather, these are on the increase throughout the world discriminately. The greater population has no relation to partition and freedom; everything has happened without their concern. But they are the real sufferers of partition [8].

The poor villagers had no cognition of disintegration between the Muslim and the Hindu getting involved them into livelihood. Though the communal riots of the city have reached in the villages, two hundred years of unity, belief, and reliance on the two communities have not been broken down. But after partition, safety did not exist in their villages. Indian Muslim and Pakistani Hindu expatriated in a day. Those who rejected partition stayed in their land. And those who accepted the fate of the refuge fear, anxiety, conflicts, and uncertainty created in their mentality.

Partition is undoubtedly a political concern. The planned evil design of the conspirators did not conceal to the people of the Indian Subcontinent. The fallen minority had to face complexities and unsafety due to the socio-political crisis. They were compelled to displace from their motherland. The minority Hindu was obliged to push in India through injustice, maltreatment, loot, rape, disdainful activity, killing, and rumor. On the other hand, the minority Muslim community were forced to displace from their mother country and were pushed in East Pakistan. Such types of entrance and departure had been going on for several decades. No practical step has not been taken despite the strong willingness of the governments of the two countries. Those who have recently left the country by paying money in case or in advance have taken shelter in the station, on the street, or in the filthy slum [9].

Huq wants to present the recent socio-political turmoil of the age very perfectly. His treatment of socio-political issues is the dominant theme of his works, among which The Firebird is the glaring example in the history of Bengali literature. As a practical artist, Huq has tried to emphasize the panromantic facts and findings of human life in the light of his literary realm. However, a culture emerges from society. Society develops based on culture. This 
culture cannot create itself. Culture is dealt with society. Society is dealt with politics where the selfish people bring about corruption and chaotic situation for the entire nations. The whole socio-political system may be disrupted if corruption blocks the way of prosperity of the country. Huq's brilliant cogitation and conscience have shed light on Bengali literature as well. His artistic techniques and approaches have enriched Bengali literature and culture. He has discovered a new aspect of socio-political trends for which his literary works have occupied a prominent place in the history of Bengali literature.

From a traditional point of view, it can be expressed in this study that Huq came of a respectable family. Huq loves Rarh and its nature wholeheartedly. The existence of birthland is dealt with his heart and mind. He has tried to familiarize the rural political and social system of the $20^{\text {th }}$-century West Bengal to all the people of the Indian Subcontinent. His perfect treatment of the socio-political system is no less than the politicians. He has a keen insight of political rule and oppression. He has contributed lots to polish and enrich the Bengali literature. If he did not write stories, fictions, and treaties, Bengali literature would lag far behind. His artistic cogitation is pure and perfect. His main concern is to discover the dark socio-political aspects through the art of characterization and plotconstruction.

\section{The Firebird as a Projection of Socio-Political Concerns}

Hasan Azizul Huq's novel The Firebird focuses on the themes of partition, riots, famine, and displacement. Huq has unveiled these concerns by portraying a middle-aged female character, which worries about her self-existence, family, society, country, time, and history of her contemporary age. Though her physical movement is confined to cocoon, her thoughts, conscience, and analytical power are beyond her psychological cognition. This woman is the narrator herself of the entire fiction, but the Bengali novelist has presented her as an anonymous character, a female protagonist.

The Firebird is set in rural Rarh, which is now known as West Bengal of the early $20^{\text {th }}$-century India. It chronicles a rural family's ups and downs. The story is told by a country housewife in a first-person narrative. She makes a powerful observation of herself and the people around her. Through her character-study, one can see the way of life of the then Rarh region. In the early part of the novel, she mostly speaks of experience within the family: births, deaths, marriages. Their fortunes blossom as they become the largest landowner in the area. But, when World War II breaks out, they are victims of cholera, shortage of crops, and, finally, the trauma of Hindu-Muslim partition. With these events, the entire novel transcends its domestic confinement.
At the end of the novel, the children of the middle-class woman set out for Pakistan, and, later, they ask their parents to join with them. Her husband agrees, but she refuses to go-her decision to remain alone at home that astonishes her husband. In answer to her husband's question, "When did you learn so much?" she said, "All these years I've only learned what you taught me and I've only said what you had me said. Now though, I've learned one or two things on my own" [10]. [My Translation]

The narrator-cum-woman, decision-maker, housewife, and other characters of the novel The Firebird are related to Huq's autobiography. His treatment of socio-political issues highlights his practical experience of what he has witnessed at every step of his life. So, he has tried to frame his sociopolitical cogitations in his popular The Firebird. His superb making creation of an anonymous female protagonist loves the freedom and existence of her birth land, for which she goes beyond the decision of the patriarchal rule and order. Despite being uneducated, she tries utmost to make her society and community fight against partition and riots, who wants to establish herself as a liberal woman. She learns from her husband how to pronounce Bengali words, phrases, or sentences. Through her utmost efforts, she enables to read the Bongabashe newspaper, hears from her husband, and ponders over the contemporary socio-political situations of the country. In this way, she takes her firm decision to do something new against partition and riots. In the autobiographical novel, The Firebird, how Hasan Azizul Huq presents socio-political concerns is the dominant theme of the study. His novel focuses on freedom of movement, exclusion of British products, famine of '43, partition of '47, and the two riots of Muslim and Hindu communities.

In the article, "The Firebird by Hasan Azizul Haque: An Oppressed Woman's Talk," Kumar points out that in the novel The Firebird, Azizul Huq has highlighted the partition through the portrayal of a simple-minded woman living in the West Bengal of Bardhhaman district [11]. The woman is the daughter of a conservative Muslim family, the housewife of a large family. World War II, communal riots, the famine of 1943, the collective massacre at the end of 1947 partition of India, being followed by the passing of one Bengal to another, have been mirrored in the novel. In the hostile social and political contexts, when all nations are being depressed, due to the endless agony of famine, many people starve and die. During the World War I and the homeland, India's independence movement, exclusion of British products as a part of the movement, the two communal riots and brutal massacres of the Hindu-Muslim over the sources of politicians' mistakes, hundreds and thousands of men, women, and children die prematurely all over Bengal and genocide takes place; the interdisciplinary sociopolitical aspects of the World War II and its horror 
reaches the village, and the division of motherland Bengal into the sword of the unchallenged bilingualism has been deeply reflected in the novel. Hasan wants to unravel the mystery of the innermost heart of the heart in politics, in the inner society, in the family, or in the familial life.

In the wake of the horrific events, like HinduMuslim communal riots, World War II, the famine of '43, and the partition of '47, many Muslim families are forcibly migrated from West Bengal to East Bengal, and countless Hindu families are displaced from East Bengal to West Bengal. The novel The Firebird is a glaring example of the Partition of the Indo-Pakistan. An innocent mother of West Bengal, while ignoring hundreds of requests from her husband and daughter, grasps her home very tightly. The writer wants to make us understand through the rigidity of the main character; there is no need to separate from the one who is born and raised on the ground. For example, while planting small shrubs from one place to another, it survives and grows; but it does not survive while transplanting a tree whose roots have penetrated deeply. For a while, it does not have the power of life.

Similarly, the woman, who, after all, argues with her husband all the time, did not dare to say, or know what is right or what is wrong. She not only contends with her husband against the partition of Bengal as a separate country of Muslims but also highlights the futility of fragmenting the motherland in the name of religion. When the husband threatens to leave her, she relies clearly upon that she would stay home alone. He thinks that despite her temporarily resisting, and she would not be able to say 'No' when he leaves after selling everything out. As a reader, one can assume while the husbands and children begin to load familial needs on the carriage, the woman in a flashy suit will also get into it. But, the truth of the father and son remains in the sand, which surprises the fact that she stays alone to the end. And, waking up in tears one night, in a large depression - she wants to wake up again. She says that in the morning when the light will come on, she will turn her face in the eastward. She will rise again from the light of the sun.

Mohammad Ali Jinnah's bipartisan division of Bengal in the sword of bipartisan theory, nor is it infinite disadvantage due to changing societies, like Hindu-Muslim separation, Azizul Huq may have fulfilled the responsibility by letting a helpless woman stand alone in such a dire situation, which is not feasible for anyone to observe in this narrow social, religious, and political reality. And this is where she would have acquired countless Bengali salutes of secular culture. (Kumar Bangladeshi Novels)

Regarding the novel The Firebird's artistic design, a young filmmaker Parvej Amin comments:
The reason for choosing the novel is emotional. The interest and passion of the people of the two Bengals are very high with the partition. Many people still remember these memories regularly. This is going to be a very challenging task. A lot of plays are composed considering the political and social contexts. All together it will be a bit difficult to do, but I like doing things, I want to take challenges. [My Translation]

Referring to the novel The Firebird, the filmmaker also argues:

The country is being divided, but a woman living in the village, how much can she know or understand all these? Even though she does not understand about partition, its impact has come into her life. At that time, the division of a country has been highlighted through this woman who has witnessed history [12]. [My Translation]

Huq's fiction is a unique feature of the country and riots. His childhood period during the famine of the forty, the partition of a country is based on religion, communal riots, and refugee crisis, but each event touches his heart. His art forever awakens this painful memory. In an interview, he says, "The partition of a country is a reflective mood in my life. The scar remains on the wound. I have tried to understand the cause of the scar" [10]. [My translation] It is because of his injury that the novelist can sense the heartbreaking suffering of the displaced people. Thus, one can presume the actual image of the partition of a country into his fiction. Significantly, few Bengali novelists, like Huq, suffer from direct loss of emigration, the deportation of refugees in the procession of the people, or feel the difficulty of being separated from the homeland.

The theme of Huq's novel The Firebird is a history of World War I, partition of the country, riots, famine, and migrant people. In 1946, the genocide of the Kolkata Riots (16-18 August) and the Noakhali Riots (10 October) broke out throughout Bengal. The riots destroy the foundation of the Hindu-Muslim community. Within 48 hours, in the riot, "The Great Calcutta Killing," five thousand people were killed; and fifteen thousand got injured and were displaced. To the narrator-cum-woman of the fiction, the ridicule and excitement of partition are not kept secret. Instead, the woman realizes: "In the name of the partition of the country, the rioters are making fun with the innocent people throughout the country" [10]. [My translation] Hindu-Muslims commit suicide in the civil war in the two countries; it is a free will to execute a plan to wipe out the other side. As a result, those who are determined to remain in their own country even after partition denies partition; there is no way for many people to leave the country. The catastrophes of riots are no less 
than those of the Kolkata-Noakhali Riots. The woman expresses thus:

Again, genocide and killing have started. Homes are being looted out; gold, grain, land, and property are being taken away; people are being displaced from homes. In cities, trains, steamers, men, women, and children are being killed indiscriminately; and thousands of people are being displaced from one country to another. I do not know the exact number of people who are banished from the state. Many people, along with everything, are coming to this country, leaving their origin. There is no place to set foot in the stations of Calcutta. At the time of famine, people have gone to Calcutta, but their numbers are on the increase throughout the city; as a result, they are now jostling entirely [10]. [My translation]

Many Muslims have migrated to Pakistan from India. But the stubborn woman refutes the politics of partition and the independence of India and Pakistan on the basis itself. It is not merely a passion or stubbornness, or rejection for rejection; she wants to know the answers to a few questions. Even if she wants to know concerning her husband and children, all these inquiries are mainly from the leaders and politicians of the country. "Why I will leave my country" [10]. Putting herself in the face of this question, the narrator clarifies her position against partition and expatriate.

Firstly, is the land-based on religion? If religion is the basis of a country, why are the same Muslim living in many countries? Religion and ethnicity are never one? How is it possible to have a separate state for religion only among people of the same language, literature, culture, history, tradition, geo-nature, plantations, and greenery fields?

Secondly, in a geographical border and multireligious country like India, is the country divided based on religion? And why are millions of Hindus living in Pakistan, and millions of Muslims living in India even after partition based on religion? So, how is Pakistan a Muslim country and India a Hindu nation?

Thirdly, why does she have to leave her country and home because her husband and children are leaving the country? In her word: "You didn't convince me that I will have to go there because my children are there. What will I do now if my husband goes there? My husband and I are not the same individuals; we are different from each other. Though he is very close to me, a man of my life, but he is a different individual" [10]. [My translation]

All children have gone to Pakistan, looking at the faces of children and grandchildren; he requests her to leave the country and decide to leave. Now, she argues that he always looks at the children's faces; children instead look at his face. In the end, he says that living in a new country will start a new life and live a life of relaxation; all will be. This time her argument is more complicated and infringing. "Don't show me any more greed. While planting small shrubs from one place to another, it survives and grows; but it does not survive while transplanting a tree whose roots have penetrated deep. For a while, it does not have the power of life" [10]. [My translation].

Such a riot, war, and bloodshed perception and position of a woman is a scarce example not only in Bengali literature but also in world literature. This woman is the symbol of the united mother, India. The novelist establishes her vitality and personality on such a solid ground, where family, society, state, religion, and reform are all obliged to her. She becomes willing to accept, reject, vandalize, and build. This force strongly rejects the partition of a country by taking a stand against war and riots [9]. Even if their husband and children emigrate, she remains alone. Partition conquers the fear of an individual, terror, loneliness, isolation, emptiness, future uncertainty; and she announces its commitment to creating a new history for the future:

What did I decide? What did I understand? I did not listen to my husband's advice, to my children's request, did all leave homestead? Man sacrifices something for a specific purpose, but to get something new, he sacrifices. For what cause did I offer? I pondered over sacrifices for a long time. Finally, I bore in mind that I have surrendered to discover my self-existence. I did not insist; I did not disobey anybody. I have tried to understand everything of my own accord. Nobody did make me know because the country has been divided where the Muslim may live along with the Hindu. If it happens, why will the partition take place? Nobody did make me understand that this country is mine because I am a Muslim.

Moreover, my children have already gone to that new land where I will have to go. If my husband leaves me, what will I do? But I am different from my husband's opinion. He has possessed another mind. I cannot live without him, but there is a psychological gap between us.

Let the morning appear, let the light appear, I will be facing towards the eastward. I will rise again, looking at the light of the sun [10]. [My translation]

From the above long quotation, Huq implies that the woman has a deep patriotic feeling and zeal in her inner heart and mind. She has firm faith in patriotism. "Patriotism is a noble virtue." This famous proverb is deeply rooted in her inner psychology, 
indeed. All her children, even her husband, have left her, but still, now she remains in the country alone. She blames nobody, but in the irony of fate, the whole country has been divided due to political and communal riots between the Muslim and the Hindu. Such riot and partition have considerably created a terrific sense in her sensibility. Due to communal riot and partition, famine has broken out throughout the entire country, for which many people, men, women, and children are victims of premature death.

Such a female riot, antagonistic attitudes towards bloody war, and pure freedom of a country are hardly noticed not only in Bengali literature but also in global literature. Huq has presented this female character as a mother figure of the Indian Subcontinent. Her inner existence and personality have been presented in such a way that family, society, state, religion, culture, and community, all of which are under her control. She enables to accept, reject, break, protest, and build everything of her own accord. By dint of her psychological power, wit, and intelligence, she rejects partition, takes her position against war and riots, and above all, stays at home alone though her husband, children, and other villagers leave the country. Partition has created fear and terrific sense, terror, loneliness, disintegration, and alienation in the mind of the people that she enables to win. She pledges to build up a novel history for the future generation. For the noble cause of the entire nation, the Bengali novelist Huq has tried to portray a female character as a symbol of women's movement and the younger female generation. According to Kenneth Waltz, "The conflict is inherent to the nature of the state. The only source of power is capabilities. Balance of power serves as deterrence against war. But it could also create or intensify tensions among nations" [13]. Similarly, Huq's treatment of socio-political crisis fosters the tensions between the two nations of the two countries, where power and hegemony create conflict and war.

\section{CONCLUSION}

Finally, it can be said that Hasan Azizul Huq is one of the most potent novelists and short story writers in the history of the Indian Subcontinent Bengali literature. Huq's cognitions and cogitations have enriched and polished Bengali literature through his literary genres, like fiction, story, and treaties. He has gathered lots of experiences about society, politics, religion, and culture throughout his life. His contemporary social and political system has been reflected in his literary cannon. Such a glaring novel, The Firebird, bears the testimony of partition and communal riots between the communities, including the Hindus and the Muslim. His patriotic writings are the perfect models of global literature, indeed. His superb making creation of an anonymous female protagonist adores and respects the freedom and existence of her birth land. Huq has wanted to discover the selfexistence of a woman belonging to the patriarchal society. The narrator-cum-woman, decision-maker, housewife, and other characters in the novel The Firebird are related to Huq's personal life. Throughout his literary career, Huq has enabled to expose sociopolitical system through the form of art of characterization, plot-construction, narratives, and story writing technique.

\section{REFERENCES}

1. Huq, Hasan Azizul. "Back cover of the novel The Firebird." Banglabazar, Dhaka: Ettadi Grantha Prakash; 2006.

2. Rahman, Mahmud. "Agunpakhi: Chronicle of a Life, Place, and Time." 2008. www.Thedailystar.net.

3. Marx, Karl and Friedrich Engels. "Introduction by Martin Malia." The Communist Manifesto. 1848. New York: Penguin group. 1998;35

4. Mamun, Al- and Bakhtiur Ahmed, interviewers. "Unveiled Hasan: Hasan Azizul Huq's Talks."

5. Shamsuzzaman, interviewer. "Unveiled Hasan: Hasan Azizul Huq's Talks.” 224.

6. Huq, Hasan Azizul. "Linguistics: Manik Bandhopadhaya." Calcutta of Oral Literature. 1981. Dhaka: Sahitha Prakash; 1994.

7. Dunne, Tim, Milja Kurki, and Smith Steve. International Relations Theories: Discipline and Diversity. New York and Oxford: Oxford University Press. 2007: 55.

8. Zaman, Niaz. "A Divided Legacy-The Partition in Selected Novels of India, Pakistan, and Bangladesh." Manohar. 2000: 41.

9. Anowar, Chandan. Hasan Azizul Huq's Fiction: Contents, Structural and Stylistic Techniques. Dhaka: Bangla Academy; 2016.

10. Huq, Hasan Azizul. The Firebird. Calcutta: Dey's Publishing and Dhaka: Swandhani Publishers; 2006.

11. Kumar, Dip. "The Firebird by Hasan Azizul Haque: An Oppressed Woman's Talk." Bangladeshi Novels.

12. The Daily Shamokal. "Long Series of Fire Bird." 16 July 2019.

13. Kasongo, Tukumbi Lumumba. Contemporary Theories of Conflict and their Social and Political Implications. 